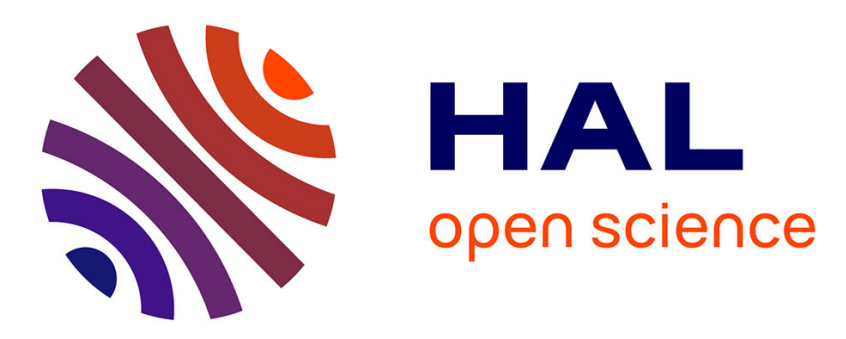

\title{
Niger seed oil biodiesel as an emulsifier in diesel-ethanol blends for compression ignition engine
}

\author{
H. V. Srikanth, Sharanappa Godiganur, Bhaskar Manne, S. Bharath Kumar, \\ Subramanya Spurthy
}

\section{- To cite this version:}

H. V. Srikanth, Sharanappa Godiganur, Bhaskar Manne, S. Bharath Kumar, Subramanya Spurthy. Niger seed oil biodiesel as an emulsifier in diesel-ethanol blends for compression ignition engine. International Journal of Ambient Energy, 2020, pp.1-11. 10.1080/01430750.2020.1783354 . hal03049166

\section{HAL Id: hal-03049166 https://hal.science/hal-03049166}

Submitted on 9 Dec 2020

HAL is a multi-disciplinary open access archive for the deposit and dissemination of scientific research documents, whether they are published or not. The documents may come from teaching and research institutions in France or abroad, or from public or private research centers.
L'archive ouverte pluridisciplinaire HAL, est destinée au dépôt et à la diffusion de documents scientifiques de niveau recherche, publiés ou non, émanant des établissements d'enseignement et de recherche français ou étrangers, des laboratoires publics ou privés. 


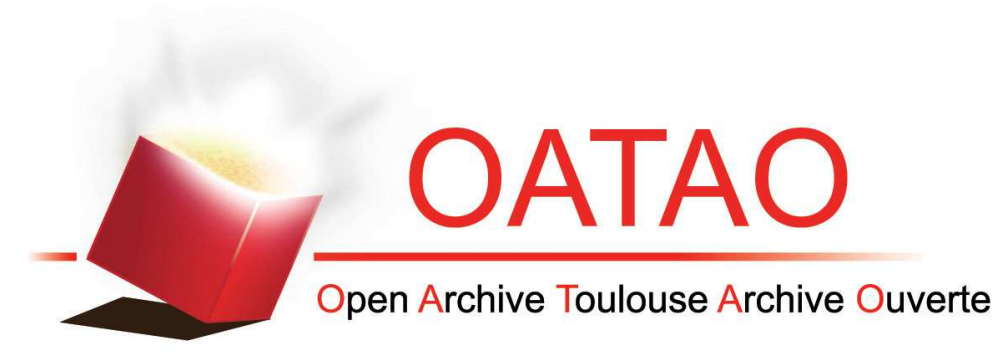

\section{Open Archive Toulouse Archive Ouverte (OATAO)}

OATAO is an open access repository that collects the work of some Toulouse researchers and makes it freely available over the web where possible.

This is an author's version published in: https://oatao.univ-toulouse.fr/27072

Official URL: https://doi.org/10.1080/01430750.2020.1783354

\section{To cite this version :}

Srikanth, H. V. and Godiganur, Sharanappa and Manne, Bhaskar and Bharath Kumar, S. and Spurthy, Subramanya Niger seed oil biodiesel as an emulsifier in diesel-ethanol blends for compression ignition engine. (2020) International Journal of Ambient Energy. 1-11. ISSN 0143-0750

Any correspondence concerning this service should be sent to the repository administrator: tech-oatao@listes-diff.inp-toulouse.fr 
DOI: $10.1080 / 01430750.2020 .1783354$

\title{
Niger seed oil biodiesel as an emulsifier in diesel-ethanol blends for compression ignition engine
}

\author{
H V Srikanth *, Sharanappa Godiganur ${ }^{\mathrm{a}}$, Bhaskar Manne ${ }^{\mathrm{b}}$, S Bharath Kumar ${ }^{\mathrm{c}}$, S Spurthy ${ }^{\mathrm{d}}$ \\ * Department of Aeronautical Engineering, Nitte Meenakshi Institute of Technology, Bangalore, India \\ ${ }^{a}$ School of Mechanical Engineering, Reva University, Bangalore, India \\ ${ }^{\mathrm{b}}$ Department of Mechanical Engineering, NITK, Suratkal, India \\ ${ }^{\mathrm{d}}$ Toulouse graduate School of Aerospace Engineering, ISAE-SUPAERO, France
}

\section{Corresponding author}

Srikanth H V

Assistant Professor

Department of Aeronautical Engineering

Nitte Meenakshi Institute of Technology

Bangalore,India

Email:holalusrikanth@gmail.com

Phone:+918147719698

\begin{abstract}
In this work, Niger seed oil biodiesel was tested as an emulsifier (10 (v/v\%) and $20(\mathrm{v} / \mathrm{v} \%))$ for diesel-ethanol (diesohol) ( $5 \mathrm{v} / \mathrm{v} \%$ to $15 \mathrm{v} / \mathrm{v} \%$ ) blends at different percentage volumes. The blends of diesohol and Niger seed oil biodiesel was tested for its suitability in a single cylinder diesel engine. The biodiesel was synthesized from Niger seed oil by transesterification process and fuel properties were found to be within the specified ASTMD6751 standards. The research was aimed to comparative performance study of the diesel engine operating on diesohol-biodiesel blends. The experimental results revealed that, with the increased ethanol and biodiesel fraction, all the blends showed improved performance and emission characteristics compared with biodiesel. Based on the outcome of this study Niger seed oil biodiesel and diesohol blends can be employed as a potential alternative fuel for existing unmodified diesel engines owing to its improved emission and performance characteristics.
\end{abstract}


Keywords: Biodiesel,Diesohol, Additives, Performance, Emission, Engine

\section{Introduction}

Over the past few decades, the depletion of world crude oil reserves, stricter emission regulations have enticed concentration of researchers throughout the world to identify new sources of fuels which are, renewable, non-toxic, environmentally friendly and has potential to quench the thirst of ever-increasing energy demands of the globe. Among the various alternative fuels studied, biodiesel and ethanol have received much attention in recent years for internal combustion (IC) engines. Several studies have been carried out by researchers on atilising biodiesel and ethanol as an alternative fuel for internal combustion (IC) engines to satisfy the demand for fossil fuel. Biodiesel and ethanol are produced from feedstocks that are generally considered to be renewable. Biodiesel can be produced from first generation feedstocks such as vegetable oils and animal fats and has been used as fuel for diesel engines. Many studies have reported the use of biodiesel fuels in diesel engines and some of them have been reviewed (Graboski \& Cormick .1998). The studies reported a substantial reduction in particulate emissions through the addition of biodiesel to diesel fuel (Durbin \& Norbeck.2002, Durbin et al.2002, Lee et al.2004). Along with biodiesel, ethanol was also investigated by various researchers as a fuel source in IC engines. Ethanol can be produced from agricultural products such as sugarcane, corn, sugar beet, molasses, cassava root, and barley by the alcoholic fermentation process. The use of ethanol in diesel fuel can significantly improve the performance of engine and reduce the particulate matter (PM) emissions for IC engines as a result of increased oxygen content in the fuel blends (Ahmed. 2001, Lu Xing et al.2004, He Bq et al. 2003, Zhang et al.2004).

Also, the blends of diesel and ethanol (diesohol) as a fuel source in IC engines have received much attention in recent years due to its improved performance, combustion and emission parameters (Rakopoulos et al.2008, Wojciech et al.2017, Jincheng et al. 2009, Achmad et al.2015, 
Arkadiusz et al. 2017, Arkadiusz et al. 2018, Yahuza et al.2015, Charalambos et al. 2013). However, there are many technical barriers to the direct use of diesohol due to the low cetane number, poor solubility in diesel fuel in cold weather and lower flash point and hence diesel engines cannot operate normally on diesel-ethanol blend without special additives (Rakopoulos et al. 2008, Wojciech et al. 2017).

Several additives were developed and tested to ensure solubility of diesel-ethanol blends (Mofijur et al.2015). Many studies have reported the effects of special additives (emulsifiers), but all have a small quantity of ethanol in the blends because additives only help for solubility and could not improve properties of blend (Hansen et al.2005, Kumar et al. 2007, Racopoulos et al. 2007, Ozer et al. 2004, Magin et al. 2008). Several investigations have reported on prevention of phase separation in diesohol by adding an emulsifier to the blends, which reduce the interfacial tension force and increase the affinity between the two liquid phases, leading to emulsion stability . However, biodiesel can be added to the diesohol blends, to prevent ethanol and Diesel fuel from phase separation. Indeed, Fatty Acid Methyl Esters (FAME) stabilises ethanol and diesel blends by acting as an amphiphile (a surface-active agent) (Hansen et al.2005, Hansen et al.2006). The miscibility of ethanol-FAME-diesel blends has been extensively studied with the help of phase diagrams at various temperatures (Fernando et al. 2005, Fernando et al.2004, Kwanchareon et al. 2007, Shi et al. 2005).

The diesel and ethanol fuels can be efficiently emulsified into a heterogeneous mixture of one miero-particle liquid phase dispersed into another liquid phase by mechanical blending in cooperation with suitable emulsifiers. The chemical structures and characteristics required for emulsification were found with biodiesel and can be effectively used as an additive to avoid phase difference in diesohol and impart excellent lubricating properties to diesel fuel (Suppes, et al. 2001, Anastopoulos et al. 2001). Also, biodiesel possesses characteristics which are similar to 
diesel fuel, which allows the use of biodiesel-diesel blends in any proportion. The addition of biodiesel as emulsifier also helps in addition of more ethanol to the diesel fuel by keeping the mixture stable and improves the tolerance of the blend to water, and it helps in storing of blends for an extended period.

Aim of this work is to replace diesel with a maximum fraction of ethanol in diesel-ethanol blends with biodiesel as an emulsifier. Ethanol is being main replacement of diesel fuel while biodiesel is added as a co-solvent and properties improver. The blends are prepared to have high oxygen content, as well as keeping the important properties within acceptable limits. A commercial diesel fuel, analysis-grade unhydrous ethanol (99.70\% purity) and biodiesel (methyl ester) derived from Niger seed oil used to make the diesel-ethanol-biodiesel blends. Experiments are conducted on a single cylinder, direct injection, naturally aspirated diesel engine to study the performance and emission characteristics of the diesel engine fueled with diesohol blends with Niger seed oil as an emulsifier.

\section{Materials and methods}

\subsection{Origin and characteristics of Niger seed}

Niger seed (Guizotia abyssinica) is probably domesticated and cultivated in Ethiopia and India in rotation with cereals and pulses and contributes about $50 \%$ of Ethiopian and $3 \%$ of Indian oilseed production. Niger seed plants grow to a height of $0.5-1.5 \mathrm{~m}$ and mature in 110 to 120 days. The crop is suitable to all types of soil, and in India, it is commonly grown on poor and acidic soils or hilly slopes that are low in fertility. Yield levels are reported to be $200-300 \mathrm{~kg} / \mathrm{ha}$ with proper management. The seed contains about $40 \%$ oil with the fatty acid composition of $75-$ $80 \mathrm{wt} \%$ linoleic acid, 7-8 wt\% palmitic and stearic acids, and 5-8wt \% oleic acid (Getinet et al. 1995). The Indian types contain $25 \mathrm{wt} \%$ oleic and $55 \mathrm{wt} \%$ linoleic acids (Nasirullah et al. 1982). 


\subsubsection{Materials}

Niger seed oil was procured from the local market of Bangalore; the oil was heated to $110^{\circ} \mathrm{C}$ and filtered through $10 \mu$ filter paper to remove moisture and suspended impurities. The chemical reagents such as methanol, $\mathrm{KOH}$ and $\mathrm{H}_{2} \mathrm{SO}_{4}$ of research grade were obtained from SigmaAldrich, India.

\subsubsection{Tranesterification of Niger seed oil biodiesel and its characterization}

The acid value and free fatty acid (FFA) content of biodiesel play a significant role in deciding the number of chemical reaction steps to be followed in transesterification, to produce biodiesel with good quality. It was estimated through the standard titrimetric method that, Niger seed oil possesses $12.6 \mathrm{mg} \mathrm{KOH} / \mathrm{g}$ oil of acid value and $6.3 \%$ of FFA. Hence, the two-step transesterification process; acid catalysed esterification followed by alkali-catalysed transesterification process was used. The acid catalysed esterification was carried out using concentrated $\mathrm{H}_{2} \mathrm{SO}_{4}(2 \mathrm{v} / \mathrm{v} \%)$ and $30(\mathrm{v} / \mathrm{v} \%)$ of methanol at $50^{\circ} \mathrm{C}$ for two hours with constant agitation. The acid catalysed esterification leads to the formation of two different liquid layers, the excess methanol with gums and impurities at the top and methyl ester with unreacted triglyceride at the bottom. The bottom phase product containing methyl ester and unreacted triglyceride was drained out and used for the second step transesterification process. In the second step reaction, products from the first step was further treated with methanol $(15 \% \mathrm{v} / \mathrm{v})$ and $\mathrm{KOH}(0.5 \% \mathrm{w} / \mathrm{w})$ at $60{ }^{\circ} \mathrm{C}$ for $2 \mathrm{~h}$. After the reaction process, the mixture was allowed to settle in a separation funnel for $12 \mathrm{~h}$, which resulted in two separate liquid layers, glycerol phase at the bottom and methyl ester at top. The methyl ester obtained was washed with de-ionised water and de-moistured by heating in a hot air oven. The properties of Niger seed oil biodiesel were tested using ASTM D6751 standards. The test methods and results are listed in Table 1. The steps involved in the synthesis of biodiesel is as shown in figure 1. 


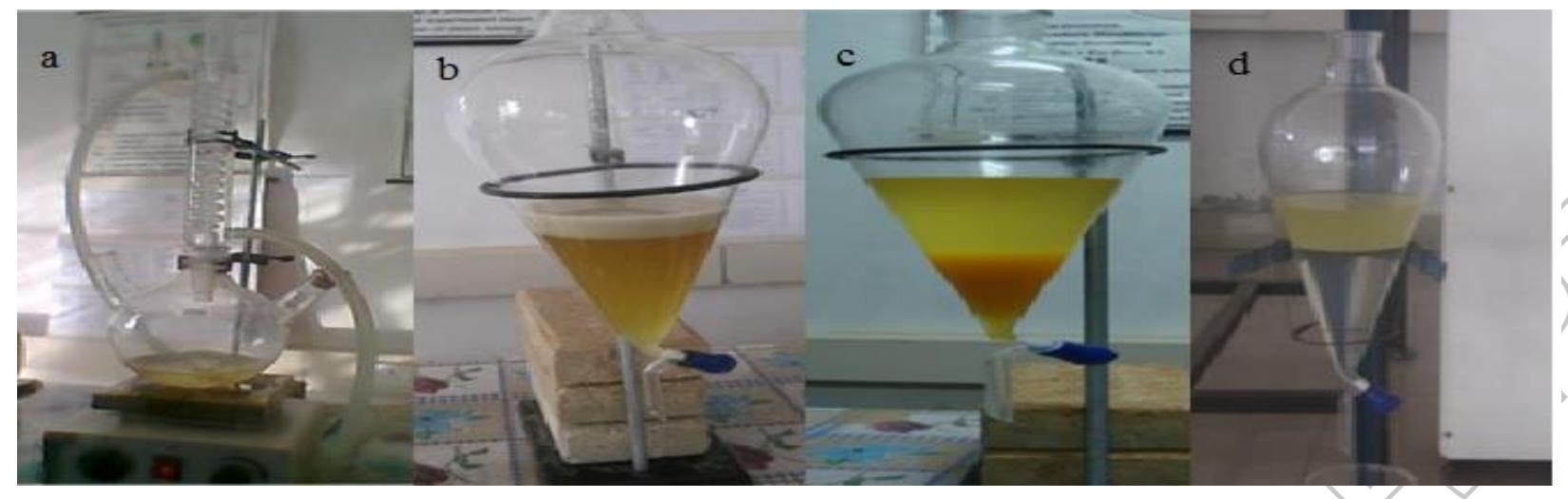

Figure 1. (a) First stage esterification process. (b) Separation of gum and sticky materials after first stage (c) Separation of glycerol after second stage transesterification (d) Water washed methyl ester after second stage of transesterification

Table 1. Properties of Nigerseed oil biodiesel

\begin{tabular}{lll}
\hline Properties & Nigerseed oil methyl ester & $\begin{array}{l}\text { ASTM D6751 } \\
\text { Test limit }\end{array}$ \\
\hline Viscosity, $\mathrm{mm}^{2} / \mathrm{sec}$, at $40^{\circ} \mathrm{C}$ & 3.752 & 1.9 to 6 \\
Density at $15^{\circ} \mathrm{C}\left(\mathrm{g} / \mathrm{cm}^{3}\right)$ & 0.855 & --- \\
Acid number $\left(\mathrm{mg} \mathrm{KOHg}{ }^{-1}\right)$ & 0.5 & Max 0.8 \\
Calorific Value $(\mathrm{kJ} / \mathrm{kg})$ & 40540 & Min 35000 \\
Flash Point $\left({ }^{\circ} \mathrm{C}\right)$ & 142 & Min 93 \\
Flash Point $\left({ }^{\circ} \mathrm{C}\right)$ & 152 & --- \\
\hline
\end{tabular}

\subsection{Blending and characterization of biodiesel-diesel-ethanol blend}

The research was aimed to conduct the comparative performance of the diesel engine operating on commercial diesel fuel as a baseline fuel and ethanol-diesel fuel (E5, E10, E15) and ethanoldiesel-biodiesel (E5B10, E10B10, E15B10, E5B20, E10B20 and E15B20) blends. The fuel blends were prepared with Niger seed oil biodiesel as an emulsifier with $10(\mathrm{v} / \mathrm{v} \%)$ and 20 $(\mathrm{v} / \mathrm{v} \%)$ in different per cent volumes of ethanol and diesel fuel blends. The diesel and ethanol blends were prepared and first and then added with Niger seed oil biodiesel as an emulsifier, the test samples were mixed thoroughly with a constant stirring speed for $15 \mathrm{~min}$. The samples were shelved for $24 \mathrm{~h}$ to observe phase separation. The significant fuel properties such as kinematic 
viscosity, calorific value and density of blended mixtures were analysed for its aptness as a fuel for a diesel engine according to ASTM D6751 standards.

\subsubsection{Kinematic Viscosity}

The kinematic viscosity (KV) of Niger seed oil biodiesel, diesel and ethanol blends were shown in fig 2. The test was carried at a temperature of $40^{\circ} \mathrm{C}$. A decreased kinematic viscosity was found with fuel blends in comparison to diesel fuel. The decrease in $\mathrm{KV}$ was due to the lower $\mathrm{kV}$ of ethanol $\left(1.22 \mathrm{~mm}^{2} / \mathrm{s}\right)$. Slight increase in the KV of fuel blends was found with the fuel blends due to the addition of biodiesel to the blends. However, the KV of fuel blends were lower in comparison with nigerseed oil biodiesel $\left(3.752 \mathrm{~mm}^{2} / \mathrm{s}\right)$ and fossil diesel $\left(3.15 \mathrm{~mm}^{2} / \mathrm{s}\right)$.

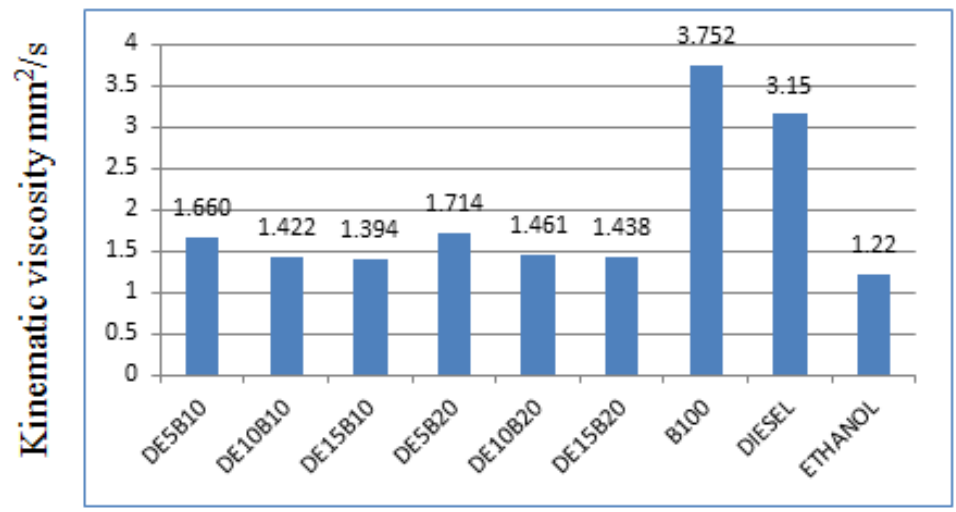

Figure 2. Kinematic viscosity of test samples

\subsubsection{Density}

The density of nigerseed oil methyl ester and blends of Diesel-Nigerseed oil biodiesel-Ethanol were as shown in fig 3 . The test were carriedout at $15^{\circ} \mathrm{C}$. From the fig 3 it can be seen that the density of the fuel blends were decreased with increase in ethanol volume compared to fossil diesel. However, there is a slight increase in density of fuel blends due with the addition of biodiesel in the fuel blends due to the higher density of biodiesel $\left(0.865 \mathrm{~g} / \mathrm{m}^{3}\right)$. 


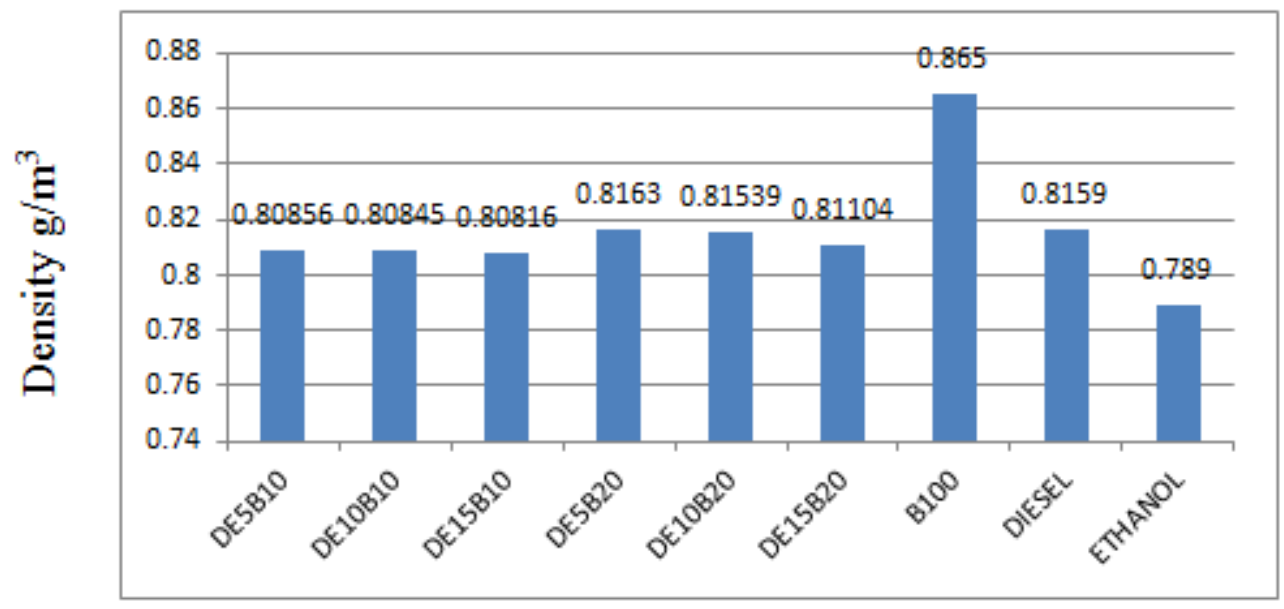

Figure 3. Density of test samples

\subsubsection{Calorific Value}

The calorific value (CV) of diesel, niger seed oil biodiesel, ethanol and blends of dieselnigerseed oil biodiesel-ethanol were as shown in fig 4. The CV of Nigerseed oil methyl ester and ethanol was found to be $40646.58 \mathrm{~kJ} / \mathrm{kg}$ and $29700 \mathrm{~kJ} / \mathrm{kg}$ respectively. The $\mathrm{CV}$ of fuel blends were found to be decreased with increase in ethanol and biodiesel in the fuel blends due to the lower calorific values of the ethanol $(29700 \mathrm{~kJ} / \mathrm{kg})$ and niger seed oil biodiesel $(40646.58$ $\mathrm{kJ} / \mathrm{kg}$ ) in comparison with $\mathrm{CV}$ of diesel fuel $(43225.6 \mathrm{~kJ} / \mathrm{kg})$.

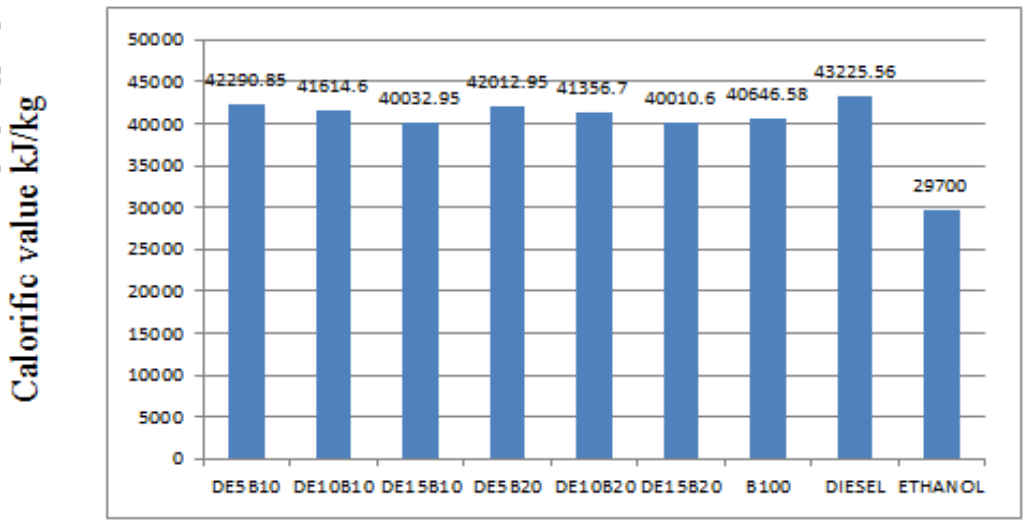

Figure 4. Calorific value of test samples 


\subsection{Test engine setup}

The experimental engine used in the current study is the one that has been typically used in agricultural applications or in industries, formally known as stationary diesel engine. This single cylinder diesel engine, which is a Kirloskar make, is manufactured and targeted for research studies, and the specifications of it are shown in Table 2. From the specifications, it could be construed that the engine has been preset to run at a constant speed of $1500 \mathrm{rpm}$ and for the current experimental study, the engine operating conditions were maintained constant at an injection pressure of $220 \mathrm{bar}$ and injection timing of $23^{\circ} \mathrm{CA}$ (crank angle) bTDC (before top dead center). Notably, mechanical type pump- nozzle fuel injection system was used, with the injector nozzle having 3 holes. In the design aspects, a piston with hemispherical combustion chamber has been used and the compression ratio of the test engine was held at 17.5. The engine is loaded by eddy current dynamometer and the force exerted on it is measured through strain gauge type load cell. The fuel flow rate was measured on volume basis using a burette and stop watch. Accordingly, the time taken for the consumption of $10 \mathrm{cc}$ of fuel was noted. Further, the air flow rate was measured by monitoring the pressure in the U-tube manometer, attached to the orifice meter in the intake air supply system. The in-cylinder pressure and cyclic variations of it were recorded using 'Engine test Express V5' engine performance analysis software. The analyzer intrinsically has an analog to digital converter with 16 channels, a charge amplifier and PC interface. To measure the in-cylinder pressure, piezo-electric transducer with an accuracy of 16:1 1 pC/bar was installed over the top of the cylinder head. The charge output of the piezo electric transducer, quantified as desired in-cylinder pressure, was amplified using the charge amplifier and was then converted into digital signal using an analog to digital converter.

In the current study, emissions such as $\mathrm{HC}$ (hydrocarbon), $\mathrm{CO}$ (carbon monoxide), $\mathrm{CO}_{2}$ (carbon dioxide) and $\mathrm{NO}_{\mathrm{x}}$ were measured using AVL 444 di-gas analyzer on dry basis. The exhaust sample to be evaluated was passed through a cold trap (moisture separator) and filter element to 
prevent water vapor and particulates from entering into the analyzer. $\mathrm{HC}$ and $\mathrm{NO}_{\mathrm{x}}$ emission were measured in ppm (parts per million) hexane equivalents, the $\mathrm{CO}$ and $\mathrm{CO}_{2}$ emission were measured in terms of percentage volume. These emissions are measured using the emission analyzer based on NDIR (non-dispersive infrared) principle by selective absorption. Further, the smoke level was measured in HSU (Hartridge smoke unit) using a standard AVL437C smoke meter before which, the exhaust gases were sent into a chamber with non-reflective surfaces and were stabilized. The smoke emission is measured based on light extinction principle wherein, the amount of light blocked by the sample of exhaust gas from the diesel engine is measured in terms of opacity. To measure the temperature of the exhaust gases, a K-type thermocouple was configured in the exhaust pipe and a digital temperature indicator reads the EGT (exhaust gas temperature). All the experiments were carried out three times and average values of the experimental values are recorded in the study. The specifications and accuracies of exhaust gas analyser and smoke meter are as shown given in Table 3. The schematic of experimental setup of the present work is shown in the figure. 5.

Table 2. Test engine specification

\begin{tabular}{cll}
\hline SL.No & Parameters & Specification \\
\hline 1 & Make and model & Kirloskar, AV 1 \\
2 & Rated brake power & $3.7 \mathrm{~kW}$ \\
3 & Rated speed & $1500 \mathrm{rpm}$ \\
4 & Number of cylinders & 1 \\
5 & Bore x stroke & $80 \times 110 \mathrm{~mm}$ \\
6 & Cooling system & Water cooled \\
7 & Compression ratio & $16.5: 1$ \\
8 & Inlet valve open [bTDC] & $4.5^{\circ}$ \\
9 & Inlet valve closed [aBDC] & $35.5^{\circ}$ \\
Electrical dynamometer & Foot mounted, continuous rating \\
10 & Type & $3 \mathrm{kVA}$ \\
11 & Alternator rating & $2800-3000 \mathrm{rpm}$ \\
12 & Speed & $220 \mathrm{~V} \mathrm{AC}$ \\
\hline
\end{tabular}

Table 3. Exhaust gas analyzer and smoke meter specifications

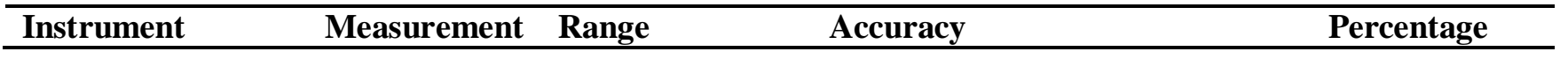




\begin{tabular}{|c|c|c|c|c|}
\hline & parameters & & & uncertainity \\
\hline \multirow{6}{*}{$\begin{array}{l}\text { AVL Digas } 444 \\
\text { gas analyzer }\end{array}$} & $\mathrm{CO}$ & $0-10 \%$ vol & $<0.6 \% \mathrm{vol}: \pm 0.03 \% \mathrm{vol}$ & $\pm 0.3 \%$ \\
\hline & $\mathrm{CO}_{2}$ & $0-20 \%$ vol & $<10 \%$ vol: $\pm 0.05 \%$ vol & $\pm 0.25 \%$ \\
\hline & $\mathrm{HC}$ & 0-20000 ppm vol & $\begin{array}{l}\geq 10 \% \text { vol: } \pm 5 \% \text { of vol } \\
<200 \text { ppm vol: } \pm 10 \text { ppm vol }\end{array}$ & $\pm 0.05 \%$ \\
\hline & $\mathrm{NO}_{\mathrm{X}}$ & $0-5000 \mathrm{ppm}$ vol & $\begin{array}{l}\geq 200 \mathrm{ppm} \text { vol: } \pm 5 \% \text { of initial } \\
\text { value } \\
<500 \text { ppm vol: } \pm 50 \mathrm{ppm} \text { vol }\end{array}$ & $\pm 0.2 \%$ \\
\hline & & & $\begin{array}{l}\geq 500 \text { ppm vol: } \pm 10 \% \text { of initial } \\
\text { value }\end{array}$ & \\
\hline & $\mathrm{O}_{2}$ & $0-22 \%$ vol & $\begin{array}{l}<2 \% \text { vol: } \pm 0.01 \% \text { vol } \\
\geq 2 \% \text { vol: } \pm 5 \% \text { of vol }\end{array}$ & $\pm 0.04 \%$ \\
\hline $\begin{array}{l}\text { AVL } 437 \\
\text { Smoke Meter }\end{array}$ & $\begin{array}{l}\text { Smoke } \\
\text { opacity }\end{array}$ & $0-100 \%$ in $\mathrm{HSU}$ & $\pm 1 \%$ full scale reading & $\pm 1 \%$ \\
\hline
\end{tabular}

\subsection{Error analysis}

J.P. Holman method of uncertainty analysis was used to determine uncertainties in measurements (Holman. 1992.). Percentage uncertainties of various performance, emission and combustion parameters were calculated using the percentage uncertainties of instruments mentioned in table 3 and table 4. Total uncertainty percentage in this experiment was determined from Equation 1.

Total percentage uncertainty in experiments $=$

Square root of $\left[(\text { uncertainty of brake power })^{2}+(\text { uncertainty of } S F C)^{2}+(\text { uncertainty of BTE })^{2}+(\right.$ uncertainty of $\mathrm{HC})^{2}+(\text { uncertainty of } \mathrm{CO})^{2}+(\text { uncertainty of } \mathrm{NOx})^{2}+\left(\text { uncertainty of } \mathrm{CO}_{2}\right)^{2}+($ uncertainty of exhaust gas temperature $\left.)^{2}\right]$

$=\left[(2.1)^{2}+(2.2)^{2}+(2.8)^{2}+(0.05)^{2}+(0.3)^{2}+(0.2)^{2}+(0.25)^{2}+(0.2)^{2}\right]$

$=3.0 \%$

Table 4.Accuracy and uncertainity in measured and calculated parameters

\begin{tabular}{llll}
\hline Sl.No & Measurements & Accuracy & Uncertainity (\%) \\
\hline 1 & Fuel flow & $\pm 0.2 \mathrm{cc}$ & $\pm 1 \%$ \\
2 & Time & $\pm 0.2 \mathrm{~seconds}$ & $\pm 1 \%$ \\
3 & Engine speed & $\pm 30 \mathrm{rpm}$ & $\pm 1.66 \%$ \\
4 & Load & $\pm 0.1 \mathrm{~kg}$ & $\pm 1 \%$ \\
6 & Crank angle encoder & $\pm 0.5^{\circ} \mathrm{CA}$ & $\pm 0.2 \%$ \\
\hline
\end{tabular}




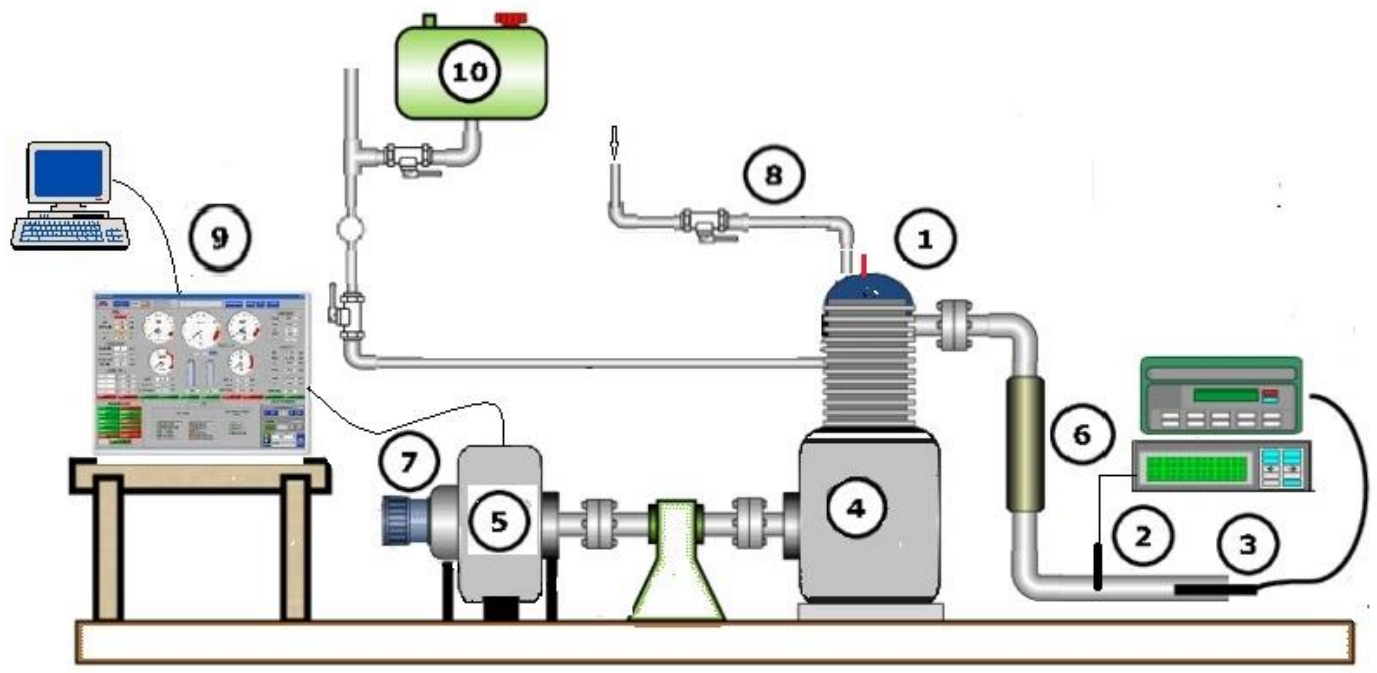

Figure 5. Schematic of experimental setup of diesel fuel engine test rig.

1-Pressure sensor

2-Smoke meter

3-Exhaust gas analyser

4-Dual cylinder CI engine

5-Eddy current dynamometer
6-Exhaust gas calorimeter

7- Crank angle encoder

8 -Water inlet to engine

9-Control panel \& computer

10-Fuel tank

\section{Results and Discussions}

The results pertaining to performance and emission characteristics of the engine are demonstrated with the help of graphs. The variation of performance characteristics such as brake thermal efficiency, brake specific fuel consumption and brake specific energy consumption and emissions parameters such as $\mathrm{CO}, \mathrm{CO}_{2}, \mathrm{NO}_{\mathrm{X}}, \mathrm{UBHC}$ and smoke density with respect to yarious loading conditions for diesel fuel, biodiesel and diesel-biodiesel-ethanol blends are discussed in the following section.

\subsection{Performance Characteristics}

\subsection{Brake Thermal Efficiency}

The variation of brake thermal efficiency (BTE) with respect to load is as shown in figure 6 . The BTE increased with load for all the fuel modes. The brake thermal efficiencies of all dieselbiodiesel-ethanol blends were higher than that of the conventional diesel fuel over the entire 
range of the load. The reason may be the extended ignition delay and the leaner combustion of biodiesel, resulting in a larger amount of fuel burned in the premixed mode of the ethanol blends. The brake thermal efficiency was increased by $2.21 \%, 3.17 \%$ and $7.95 \%$ respectively with $5 \%$, $10 \%$ and $15 \%$ of ethanol in diesel-biodiesel-ethanol blends compared with B100 at the maximum load. The brake thermal efficiencies of DE5B10, DE10B10, and DE15B10 are 5.640, $6.57 \%$ and $11.19 \%$ higher than the diesel fuel at maximum load. The maximum brake thermal efficiency was observed with DE15B10 at all the loading conditions of the diesel engine (11.19\% and 7.95\% higher than that of diesel fuel and B100 respectively at full load of the engine). It may be attributed to the rapid premixed combustion part possessed by ethanol blends because of improved mixing during ignition delay, oxygen enrichment, leading to higher percentage of constant volume combustion and to the lower heat losses and leaner combustion [39]. The improvement of diffusive combustion phase would have also resulted due to oxygen enrichment. Based on these reasons, the energy consumption rate of blends decreased and BTE increased as reported in (Lu et al/2004, Racopoulos et al. 2007, ] Magin et al. 2008). 


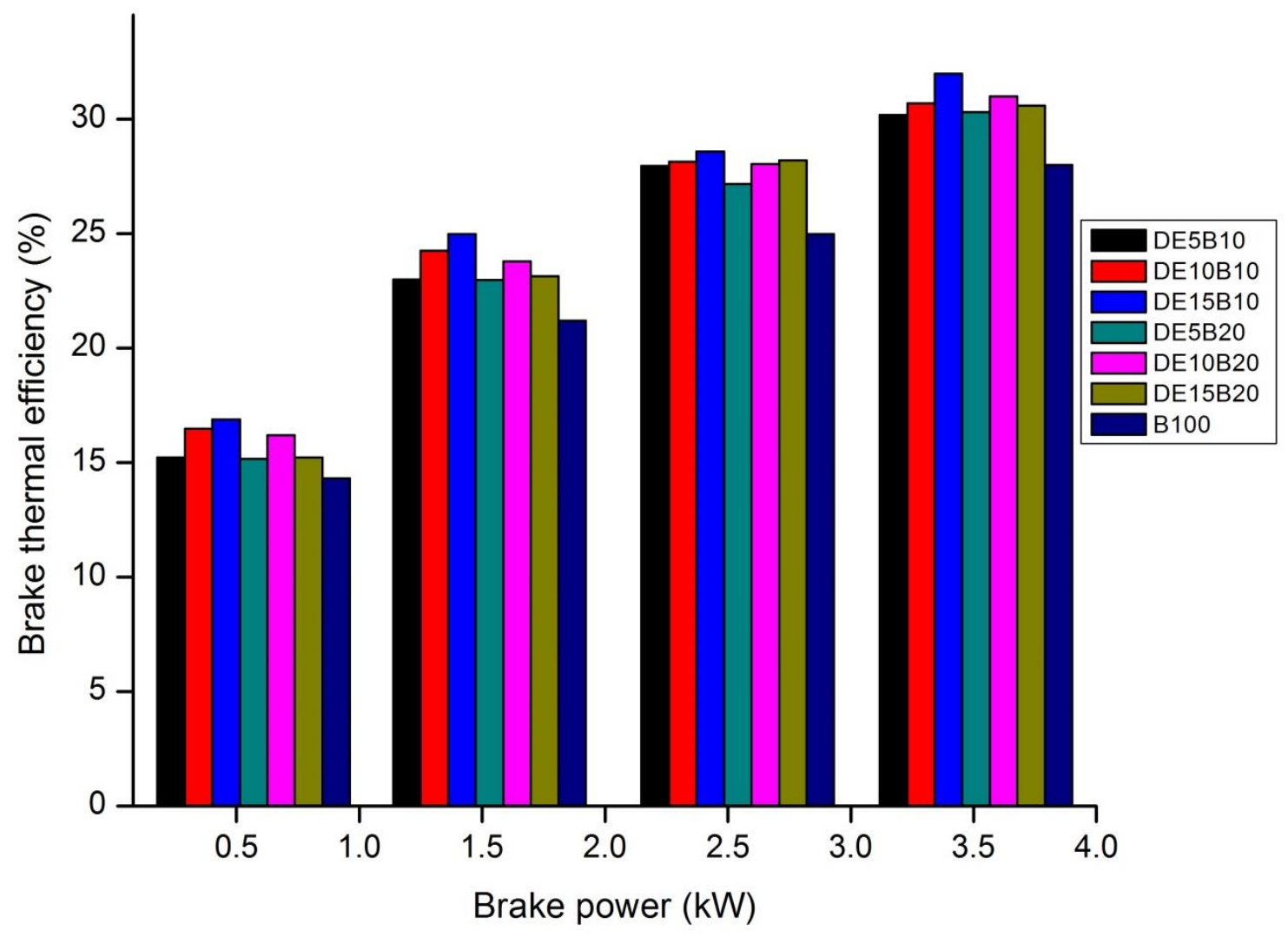

Figure 6. Variation of brake thermal efficiency with brake power

\subsubsection{Brake Specific Fuel Consumption}




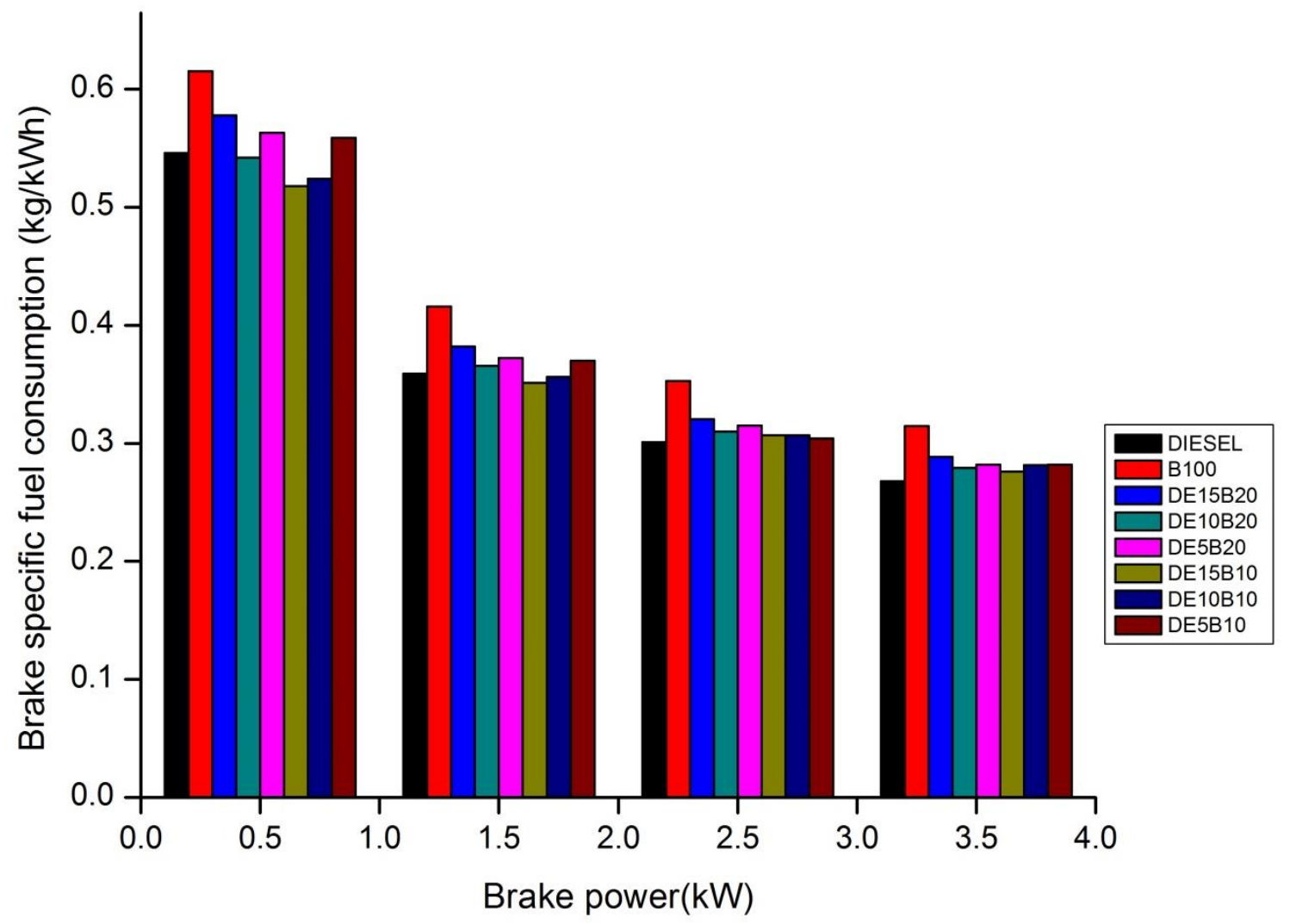

Figure 7. The variation of brake specific fuel consumption (BSFC) with brake power

The variation of brake specific fuel consumption (BSFC) with load for diesel fuel, biodiesel and diesel-biodiesel-ethanol blends is as shown in the Fig. 7. The BSFC reduced with load for all the fuel modes. The BSFC of B100 is $16.6 \%$ higher than that of the diesel fuel at maximum load of the engine. The BSFC increased by $8.08 \%, 10.71 \%$ and $12.58 \%$ respectively with the blends DE5B10, DE10B10 and DE15B10 compared with diesel and BSFC was found to be increased by $8.42 \%, 11.66 \%$ and $15.25 \%$ respectively with the blends DE5B20, DE10B20 and DE15B20 compared with diesel. The BSFC increased with the increase of ethanol percentage in the dieselbiodiesel-ethanol blends at all loading conditions of the engine. This behavior is attributed to heating value per unit mass of the ethanol, which is noticeably lower than that of the diesel fuel. Therefore, the amount of fuel introduced into the engine cylinder for a desired fuel energy input has to be greater with the ethanol also highly oxygenated ethanol blending into the blends leads to leaner combustion resulting in higher BSFC (Abdel-Rahman 1998, Ajav et al. 1999). 


\subsubsection{Brake Specific Energy Consumption}

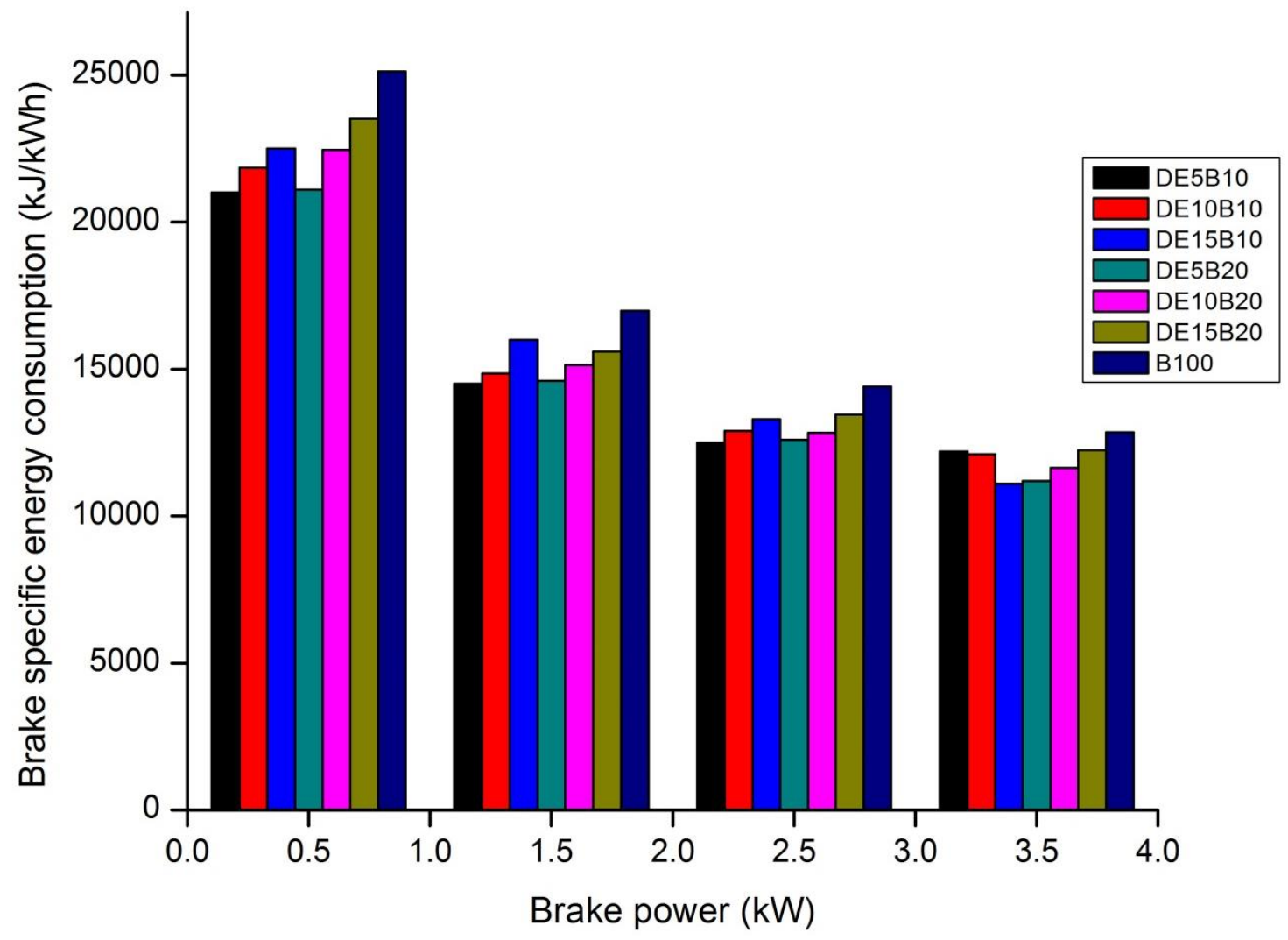

Figure 8. The variation of brake specific energy consumption (BSEC) with brake power

The variation of brake specific energy consumption (BSEC) with load for diesel fuel, biodiesel and diesel-biodiesel-ethanol blends is as shown in the Fig. 8. In all cases, BSEC decreased sharply with increase in percentage of load for all fuels. The main reason for this could be that the percent increase in fuel required to operate the engine is less than the percent increase in brake power, because relatively less portion of the heat is lost at higher loads. The BSEC for all blends was higher than that of diesel. This trend was observed due to lower calorific value, with increase in biodiesel and ethanol percentage in blends. This trend of BSEC with increasing load in different biodiesel blends were also reported by some researchers (Raheman et al. 2004) while testing biodiesel obtained from karanja oil. The BSEC of DE5B10, DE10B10 and DE15B10 are $3.38 \%, 7.41 \%$ and $11.11 \%$ high respectively, when compared with diesel. And the BSEC of B100 is $13.19 \%$ more than diesel at maximum load. The BSEC of DE5B20, DE10B20 and 
DE15B20 are $0.09 \%, 4.71 \%$ and $11.29 \%$ more respectively, when compared with diesel at maximum load.

\subsection{Emission Characteristics}

\subsubsection{Carbon-dioxide}

The variation of carbon dioxide with brake power for diesel fuel, biodiesel and diesel-biodieselethanol blends is as shown in the Fig. 9.

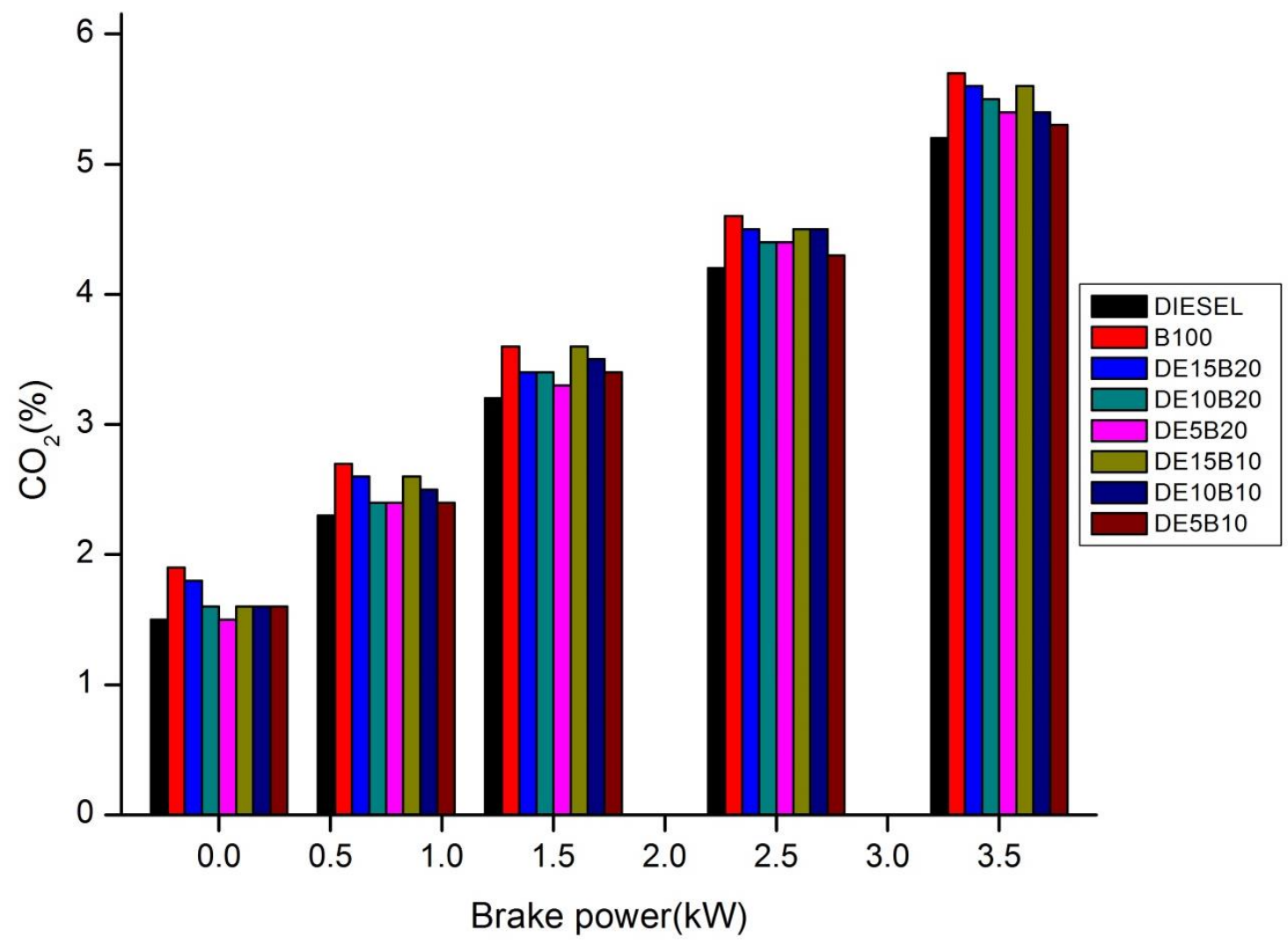

Figure 9. Variation of $\mathrm{CO}_{2}$ with brake power

The $\mathrm{CO}_{2}$ emissions increased with brake power for all the fuel modes. The $\mathrm{CO}_{2}$ emissions of B100, DE5B10, DE10B10 and DE15B10 were slightly higher than those of diesel fuel. The $\mathrm{CO}_{2}$ emissions increased by $3.7 \%, 2.30 \%$ and $3.03 \%$ respectively with $5 \%, 10 \%$ and $15 \%$ of ethanol in diesel-biodiesel-ethanol blends compared to diesel at maximum load condition. And also the carbon dioxide emission of B100 increases a value of 5.45\% when compared to diesel at 
maximum load condition. The $\mathrm{CO}_{2}$ emissions of DE5B20, DE10B20 and DE15B20 were slightly higher than those of diesel fuel. The $\mathrm{CO}_{2}$ emissions increased $2.32 \%, 4.54 \%$ and $6.66 \%$ respectively with $5 \%, 10 \%$ and $15 \%$ of ethanol in diesel-biodiesel-ethanol blends compared to diesel. The increase in $\mathrm{CO}_{2}$ with load for all fuels tested due to the presence of more fuelinside the combustion chamber causing complete combustion and coverts $\mathrm{CO}$ into $\mathrm{CO}_{2}$ emissions. The result shows that carbon dioxide emission for $\mathrm{B} 100$ \& blends is more than that of diesel. Since diesel constitutes of the pure hydrocarbon chain, lower $\mathrm{CO}_{2}$ is obvious. It is found that addition of biodiesel and ethanol to the blends decreases the $\mathrm{CO}_{2}$ emissions. The ethanol and biodiesel enhances the combustion rate and also supplies more oxygen which reduces $\mathrm{CO}_{2}$ emissions. The maximum $\mathrm{CO}_{2}$ emission for ethanol blends was observed for DE15B10 at full load condition and this is owing to the complete combustion with intrinsic oxygen molecules present in ethanol and biodiesel . Further, reduction in viscosity of blends also played a key role in a reduction in $\mathrm{CO}_{2}$ emission

\subsubsection{Unburnt hydro-carbon}

The variation of hydro-carbon emissions with brake power for diesel fuel, biodiesel and dieselbiodiesel-ethanol blends is as shown in the Fig. 10. The UBHC emissions of the pure biodiesel and diesel-biodiesel-ethanol blends were higher at low and medium loads and significantly lower at higher loads than diesel fuel. It is due to the better combustion achieved at higher loads. The $\mathrm{HC}$ emissions increased with increase of ethanol percentage in the diesel-biodiesel-ethanol blends. Higher $\mathrm{HC}$ emission indicates presence of unburnt ethanol emitted in the exhaust due to the larger ethanol dispersion region in the combustion chamber. The $\mathrm{HC}$ emissions were $11.11 \%, 5.55 \%$ and $7.77 \%$ lower than those of diesel fuel with $5 \%, 10 \%$ and $15 \%$ of ethanol addition at full load of the engine. Among these blends, the blend of $85 \%$ diesel, $10 \%$ biodiesel and 5\%ethanol had the lowest $\mathrm{HC}$ emissions at the full load of the engine. The pure biodiesel produced lowest $\mathrm{HC}$ emissions among all fuels and were 33.3\% lower than those of diesel fuel. 
Biodiesel has a higher cetane number than conventional diesel, resulting in more complete combustion in the cylinder.

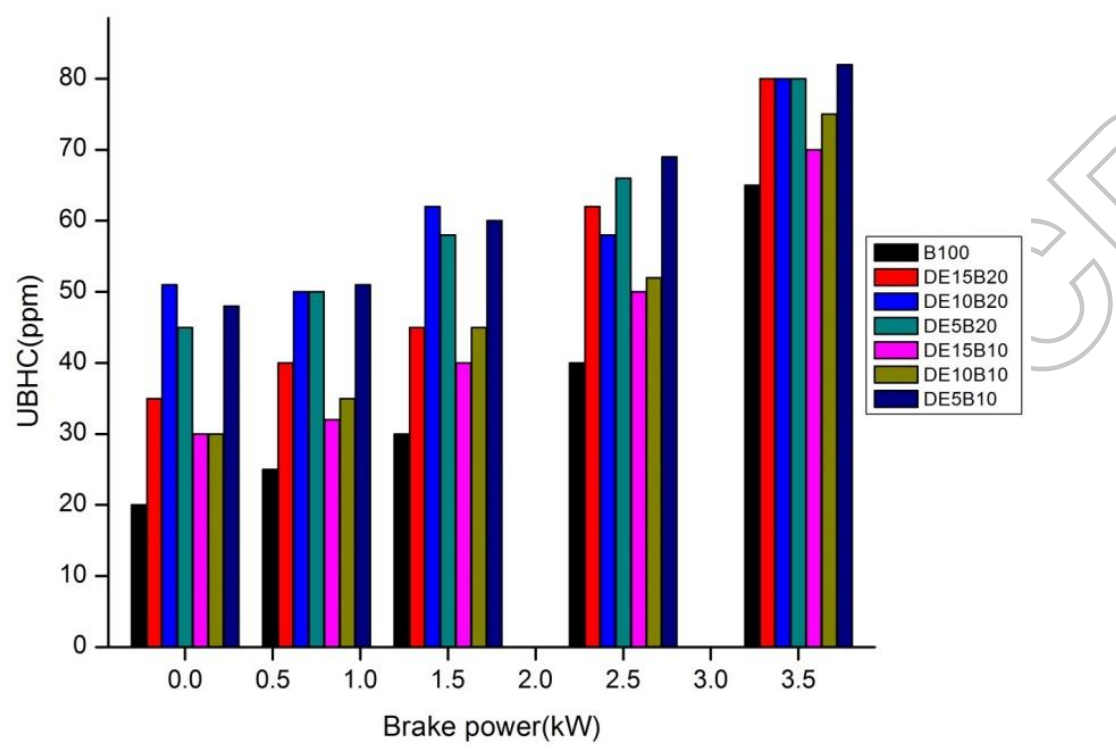

Figure 10. Variation of unburnt hydro-carbon (UBHC) with brake power

\subsubsection{Oxides of nitrogen}

The variation of oxide of nitrogen with brake power for diesel fuel, biodiesel and dieselbiodiesel-ethanol blends is as shown in the Fig. 11. The NOx emissions of biodiesel, and dieselbiodiesel-ethanol blends increased with increase in load and it is more at medium and high loads than diesel fuel. It is due to the higher oxygen content and combustion temperature of the biodiesel and the ethanol blends at medium and high loads. The NOx emissions increased with the increase of ethanol percentage in diesel-biodiesel-ethanol blends. The NOx emissions of DE5B10, DE10B10 and DE15B10 were 1.49\%, 2.95\% and 4.16\% higher than diesel at full load of the engine. The oxide of nitrogen emission of B100 was also found to be $8 \%$ higher than the diesel. It is observed that $\mathrm{NO}$ emissions are increased for ethanol blended fuels compared to diesel fuel. The ethanol blends are having the oxygen contents, low viscosity which can lead to better mixing, improved combustion and rise in-cylinder temperature. More ignition delay of 
blend due to lower Cetane index increased fuel accumulation during delay period. That is resulted in increased the rate of premixed combustion and peak heat release rate at high loads. The blend DE15B20 shows a highest NOx emission, 7.07\% higher than diesel at full load of the engine.

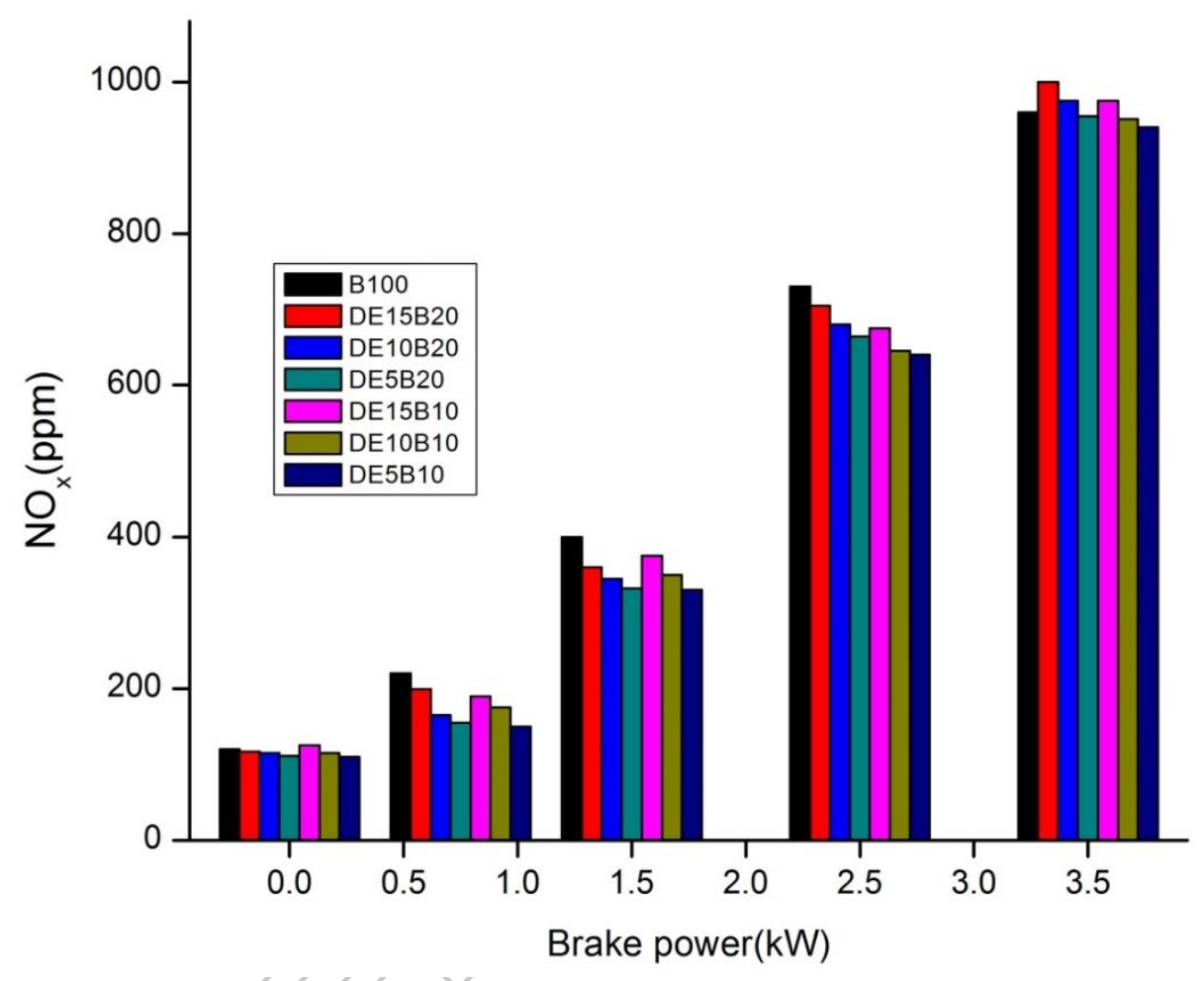

Figure 11. Variation of oxide of nitrogen (NOx)with brake power

\subsubsection{Carbon-monoxide emission}

The variation of carbon monoxide with load for diesel fuel, biodiesel and diesel-biodieselethanol blends is as shown in the Fig. 12. The CO emissions slightly increased at low and medium loads and increased significantly at higher loads with all the fuel modes. The CO emissions of the diesel-biodiesel-ethanol blends were not much different from that of conventional diesel at low and medium loads as shown in the figure 12. However, the CO emissions of these blends decreased significantly, when compared with those of conventional diesel at full load of the engine. This is due to the higher amount of oxygen with the ethanol and biodiesel addition, which will promote the further oxidation of $\mathrm{CO}$ during the engine exhaust 
process. The results showed that the $\mathrm{CO}$ emissions reduced with increase of ethanol percentage in the diesel-biodiesel-ethanol blend. The CO emissions reduced by $11.11 \%, 22.22 \%$ and $33.3 \%$ than the conventional diesel with the addition of $5 \%, 10 \%$ and $15 \%$ of ethanol in $20 \%$ biodiesel in the blends. The lowest CO emission was found with the blend DE15B20.

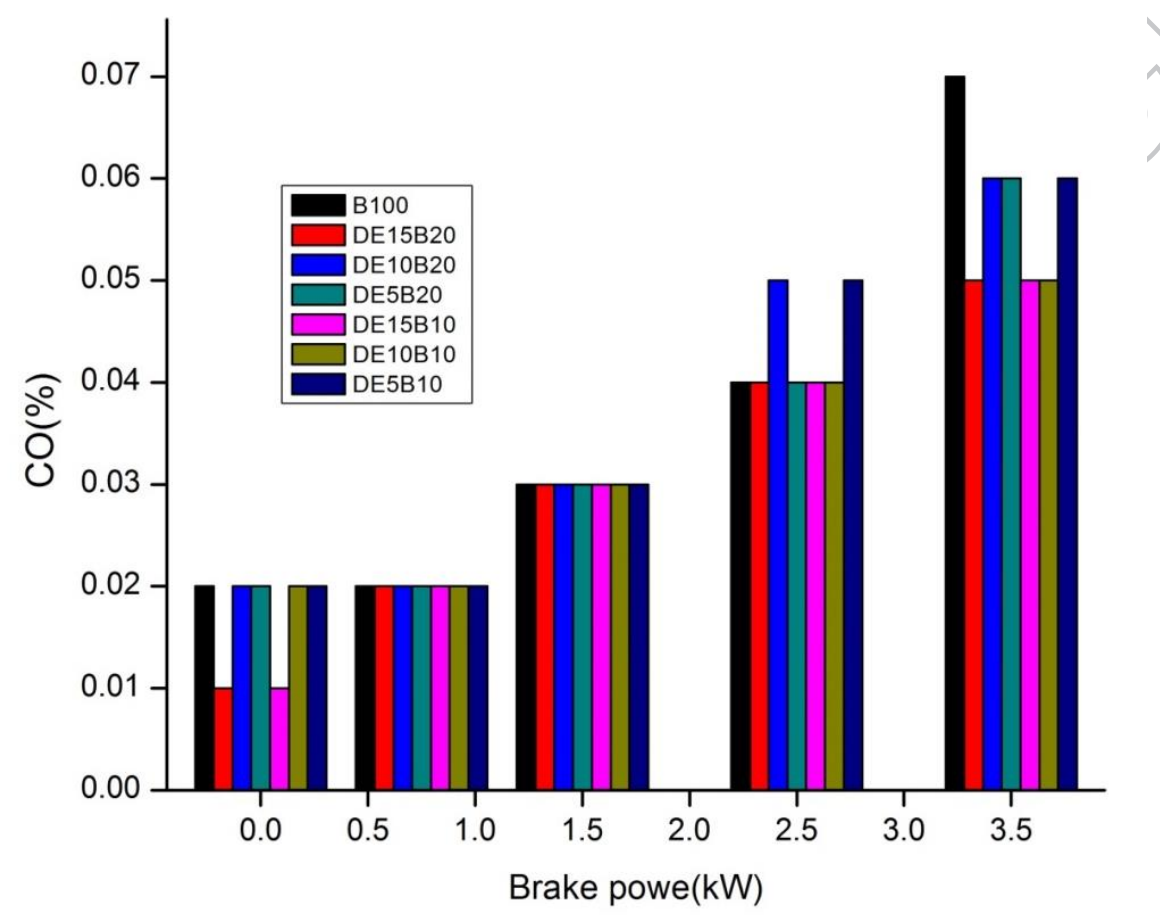

Figure 12. Variation of carbon monoxide (CO) with brake power

\subsubsection{Smoke density}

The variation of smoke density with brake power for diesel fuel, biodiesel and diesel-biodieselethanol blends is as shown in the Fig. 13. The smoke density increased with the load for diesel fuel, biodiesel and diesel-biodiesel-ethanol blends. The smoke density of the biodiesel was higher than all the other test fuels. The lowest smoke density was found with DE15B20 blend, the decreased smoke emission was due to the complete combustion of fuel due to the presence of higher intrinsic oxygen present in ethanol and biodiesel. 


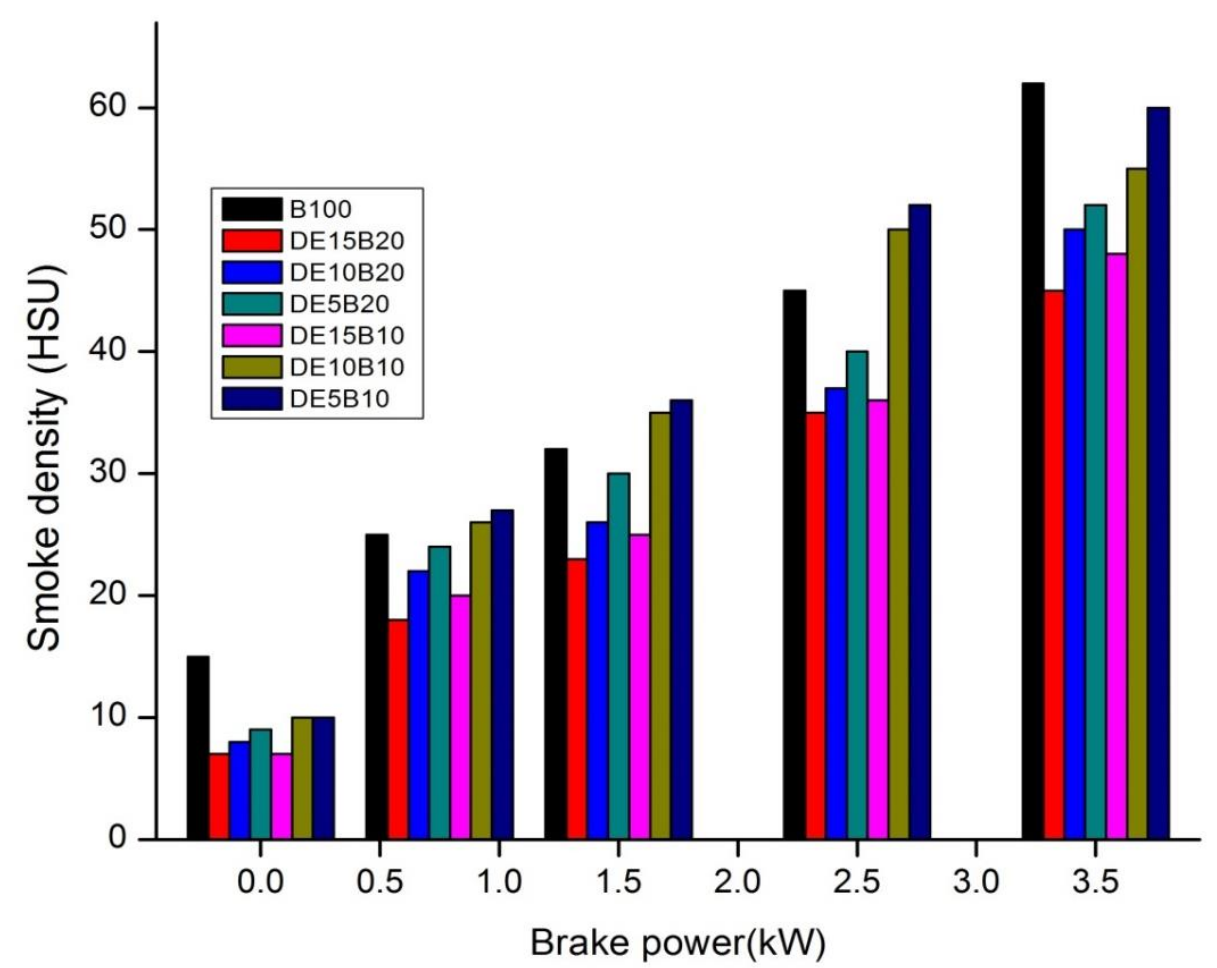

Figure 13. The variation of smoke density with brake power

\subsubsection{In-cylinder pressure}

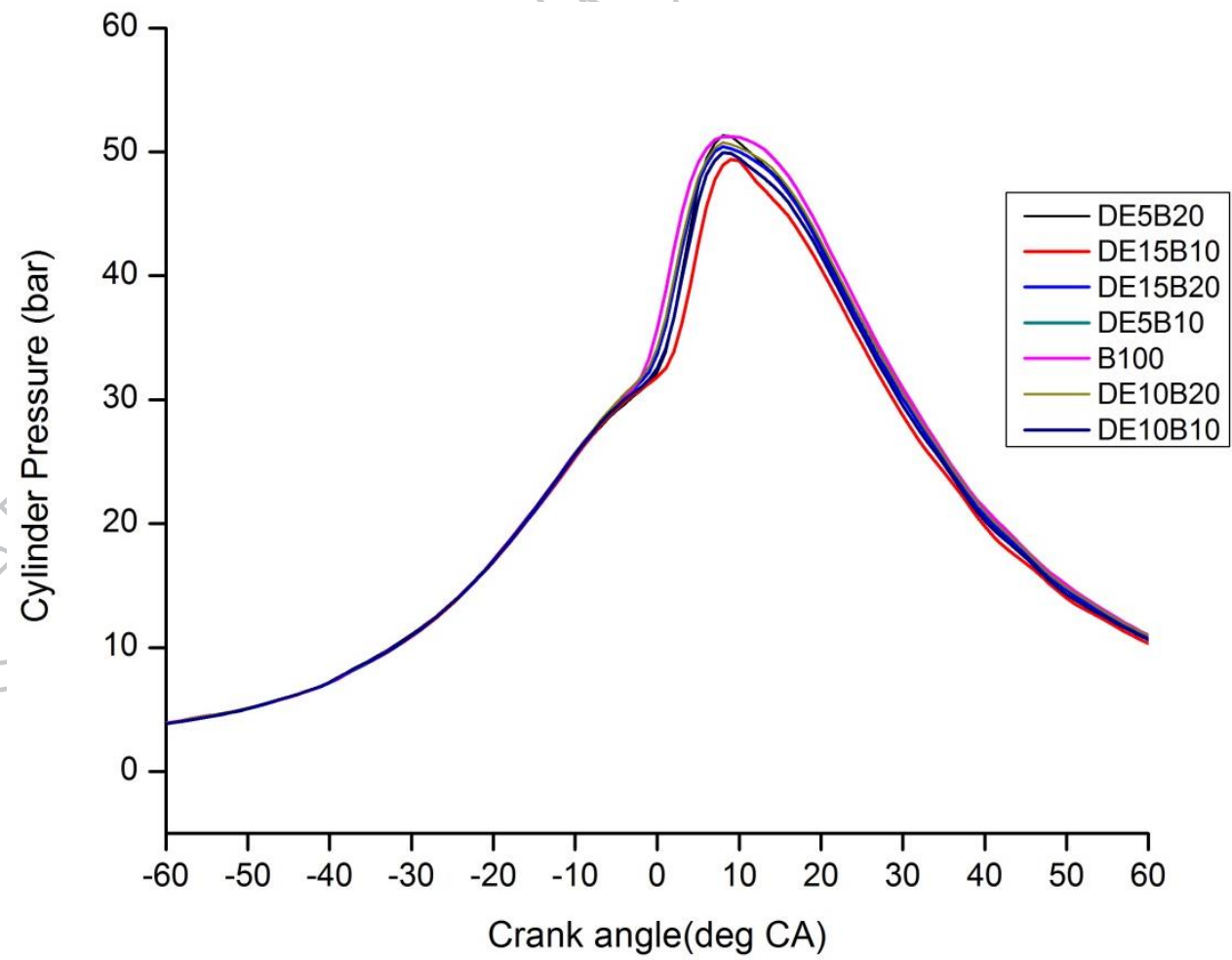

Figure 14. The variation of In-cylinder pressure with crank angle at full load condition 
Figure 14 shows the in-cylinder pressure variation with respect to crank angle for different fuels at full load condition. The variation is observed at the start of combustion and peak pressure. The maximum pressure observed for biodiesel fuel is 51 bar at $6^{\circ}$ aTDC, followed by other fuel blends. However, it can be seen that for all the test fuels the maximum pressure is reached after top dead centre. Also, the start of combustion shifts towards right for alcohol biodiesel blends compared to pure biodiesel. The shifting towards right denotes the retarded start of combustion. This tendency of delay in ignition is due to the lower cetane number of alcohols and its blends with biodiesel. The decrease in cylinder pressure with alcohol blends can be attributed to lower gas temperature, higher latent heat of evaporation, higher specific heat and lower heat of reaction with alcohol blended biodiesel compared to neat biodiesel (Anand et al.2011).

\section{Conclusions}

The performance and emission characteristics of single cylinder diesel engine fueled with , Niger seed oil biodiesel, and diesel-biodiesel-ethanol blends were investigated. The conclusions of this investigation are as follows:

- The Niger seed oil biodiesel was synthesized using two step transesterification process, the fuel properties of biodiesel were within the specified ASTMD6751 standards.

- The Niger seed oil biodiesel was used as additives from $5 \mathrm{v} / \mathrm{v} \%$ to $20 \mathrm{v} / \mathrm{v} \%$ in dieselethanol blends to enhance the solubility of ethanol in diesel fuel.

- The maximum brake thermal efficiency was observed with DE15B10 at all the loading conditions of the diesel engine, it was found that an increase of $11.19 \%$ and $7.95 \%$ than diesel fuel and B100 respectively at full load of the engine.

- The BSFC increased with the increase of ethanol percentage in the diesel-biodieselethanol blends at all loading conditions of the engine .The BSFC increased by $8.42 \%$, $11.66 \%$ and $15.25 \%$ respectively with the blends DE5B20, DE10B20 and DE15B20 compared with diesel.

- The $\mathrm{CO}_{2}$ emission was found to be increased with increase in ethanol in the fuel blends, maximum $\mathrm{CO}_{2}$ emission was observed for $\mathrm{DE} 15 \mathrm{~B} 10$ at full load condition and this is owing to the complete combustion owing to intrinsic oxygen molecules present in ethanol and biodiesel. 
- The blend DE15B20 shows a highest NOx emission, 7.07\% higher than diesel at full load of the engine, which is due to presence of higher intrinsic oxygen present in ethanol and biodiesel which increases the cylinder temperature and further formation of NOx.

- The smoke density of the biodiesel was higher than all the other test fuels. The lowest smoke density was found with DE15B20 blend, the decreased smoke emission was due to the complete combustion of fuel at higher load condition.

- The in-cylinder pressure for the biodiesel is $51 \mathrm{bar}$ at $6^{\circ}$ aTDC and followed by other fuel blends. This is due to the lower cetane number of alcohols, lower gas temperature, higher latent heat of evaporation, higher specific heat and lower heat of reaction with alcohol blended biodiesel compared to neat biodiesel.

\section{References}

Abdel-Rahman AA. On the emissions from internal-combustion engines. Int $\mathrm{J}$ Energy Res 1998;22:483-513.

Achmad Prapti janto, Aam Muharam, Arifin Nur, Yanuandri Putrasari, Effect of Ethanol

Percentage for Diesel Engine Performance Using Virtual Engine Simulation Tool, Energy

Procedia, 2015; 68: 345-354.

Ahmed I. Oxygenated diesel: emissions and performance characteristics of ethanol-diesel blends in CI engines. SAE Technology Paper 2001-01-2475.

Ajav EA, Singh B, Bhattachary TK. Experimental study of some performance parameters of a constant speed stationary diesel engine using ethanol-diesel blends as fuel. Biomass Bioenergy 1999; 17:357-65.

Anand K, Sharma RP, Mehta PS. Experimental investigation on combustion, performance and emission characteristics of neat karanji biodiesel and its methanol blend in a diesel engine. Biomass Bioenergy, 2011; 35: 533-41.

Anastopoulos G., Lois, E., Serdari, A., Zanikos, F., Stournas, S. and Kalligeros, S. Lubrication Properties of Low-Sulfur Diesel Fuels in the Presence of Specific Types of Fatty Acid Derivatives, Energy \& Fuels, 2001; 15: 106-112.

Arkadiusz Jamrozik, Wojciech Tutak, Michał Gruca and Michał Pyrc,Performance, emission and combustion characteristics of CI dual fuel engine powered by diesel/ethanol and 
diesel/gasoline fuels, Journal of Mechanical Science and Technology 2018; 32 (6): 29472957.DOI 10.1007/s12206-018-0551-8.

Arkadiusz Jamrozik, Wojciech Tutak, Michał Pyrc, Michał Sobiepański, Effect of diesel/biodiesel/ethanol blend on combustion, performance and emissions characteristics on a direct injection diesel engine, Thermal Science , 2017, 21, No. 1B, 591-604.

Charalambos A. Chasos, George N. Karagiorgis, and Chris N. Christodoulou ,Diesel Internal Combustion Engine Emissions Measurements for Methanol-Based and Ethanol-Based Biodiesel Blends,Conference Papers in Energy, 2013, Article ID 162312. DOI: $10.4172 / 2157-7048.1000256$.

Durbin TD, Collins JR, Norbeck JM, Smith MR. Effects of biodiese, biodiesel blends and a synthetic diesel on emissions from light heavy-duty diesel vehicles. Environ Sci Technol 2002;34:349-55.

Durbin TD, Norbeck JM. Effects of biodiesel blends and EC-diesel on emissions from light heavy-duty diesel vehicles. Environ Sci Techno12002;36:1686-91.

Fernando S, Hanna M. Development of a noyel biofuel blend using ethanol- biodiesel-diesel microemulsions: EB-diesel. Energy Fuel 2004; 18:1695-703.

Fernando S, Hanna M. Phase behaviour of the ethanol-biodiesel-diesel microemulsion system. Transaction of ASAE, 2013;48(3):903-08.

Getinet, A. and A. Teklewold. An agronomic and seed-quality evaluation of niger(Guizotia abyssinica Cass.) germplasm grown in Ethiopia. Plant Breed.1995; 114:375-376.

Graboski MS, McCormick RL. Combustion of fat and vegetable oil derived fuels in diesel engines. Prog Energy Combust Sci 1998;24:125-64.

Hansen AC, Gratton MR, Yuan W. Diesel engine performance and NOx emissions from oxygenated biofuels and blends with diesel fuel. Trans ASABE 2006;49:589-95.

Hansen AC, Zhang Q, Lyne PWL. Ethanol-diesel fuel blends - a review. Bioresour Technol 2005;96:277-85.

Hansen Alan C, Zhang Qin, Lyne Peter WL. Ethanol-diesel fuel blends - a review. Bioresour Technol, 2005;96:277-85.

He BQ, Shuai SJ, Wang JX, He H. The effect of ethanol blended diesel fuels on emissions from a diesel engine. Atmos Environ 2003;37:4965-71. http://dx.doi.org/10.1155/2013/162312. 
Jincheng Huang, Yaodong Wang, Shuangding Li, Anthony P, Roskilly, Hongdong Yu, and Huifen Li, Experimental investigation on the performance and emissions of a diesel engine fuelled with ethanol-diesel blends, Applied Thermal Engineering, 2009; 29(12), 2484-2490.

Kumar Chandan, Athawe M, Aghav YV, Babu Gajendra, Das LM. Effects of ethanol addition on performance, emission and combustion of DI diesel engine running at different pressures. SAE Paper, 2007-01-0626.

Kwanchareon P, Luengnaruemitchai A, Jai-In S. Solubility of a diesel- in an automotive diesel engine. Fuel, 2008;87(1):25-31.

Lee SW, Herage T, Yong B. Emission reduction potential from the combustion of soy methyl ester fuel blended with petroleum distillate fuel. Fuel, 2004;83:1607-13.

Lu Xing-Cia, Yang JG, Zhang WG, Huang Z. Effect of Cetane number improver on heat rate and emissions of high speed diesel engine fueled with ethanol- diesel blend fuel. Fuel 2004;83:2013-20.

Magin L, Octavio A, Herreros Jose M. Emissions from a diesel-bioethanol blend on heat rate and emissions of high speed diesel engine fueled with ethanol- diesel blend fuel. Fuel 2004;83:2013-20.

Mofijur M.G. Rasul, J. Hyde, Recent Developments on Internal Combustion Engine Performance and Emissions Fuelled With Biodiesel-Diesel-Ethanol Blends, Procedia Engineering, 2015; 105: 658 - 664.

Nasirullah, K., T. Mallika, S. Rajalakshmi, K.S. Pashupathi, K.N. Ankaiah, S. Vibhakar, M.N. Krishnamurthy, K.V. Nagaraja and O.P. Kapur. Studies on niger seed oil (Guizotia abyssinica) seed oil. J. Food Sci. and Technol. 1982; 19:147-149.

Ozer C, Ismet C, Nazım U. Effects of ethanol addition on performance and emissions of a turbocharged indirect injection Diesel engine running at different injection pressures. Energy Convers Manage 2004;45:2429-40.

Racopoulos CD, Antonopoulos KA, Racopoulos DC. Experimental heat release analysis and emissions of a HSDI diesel engine fueled with ethanol-diesel fuel blends. Energy, 2007;32:1791-808.

Racopoulos CD, Antonopoulos KA, Racopoulos DC. Experimental heat release analysis and emissions of a HSDI diesel engine fueled with ethanol-diesel fuel blends. Energy 2007;32:1791-808. 
Raheman H., et.al., Diesel Engine Emissions and Performance from Blends of Karanja Methyl Ester and Diesel, Elsevier, Biomass and Bioenergy,2004; 27: 393-39.

Rakopoulos D C, Rakopoulos C D, Kakaras E C, Giakoumis E G, Effects of ethanol-diesel fuel blends on the performance and exhaust emissions of heavy duty DI diesel engine, Energy Conversion and Management, 2008; 49 (11): 3155-3162.

Shi X, Yu Y, He H, Shuai S, Wang J, Li R. Emission characteristics using methyl soyateethanol-diesel fuel blends on a diesel engine. Fuel 2005;84:1543-9.

Suppes, G. J., Goff, M., Burkhart, M. L., Bockwinkel, K., Mason, M.H., Botts, J.B. and Heppert, J.A. Multifunctional Diesel Fuel Additives from Triglycerides, Energy \& Fuels, 2001; 15: 151-157.

Wojciech Tutak, Arkadiusz Jamrozik, Michał Pyrc, Michał Sobiepański, A comparative study of co-combustion process of diesel-ethanol and biodiesel-ethanol blends in the direct injection diesel engine, Applied Thermal Engineering,2017; 117: 155-163.

Yahuza I and Dandakouta H, A Performance Review of Ethanol-Diesel Blended Fuel Samples in Compression-Ignition Engine, J Chem Eng Process Technol, 2015; 6 (5).

Zhang RD, He H, Shi XY, He BQ, Wang JX. Preparation and emission characteristics of ethanol-diesel fuel blends. J Environ Sci 2004;16:793-6. 